\title{
Hepatoprotective Screening of Seriphidium kurramense (Qazilb.) Y.R. Ling
}

\author{
Maroof Ali, ${ }^{1}$ Hidayat Hussain, ${ }^{2}$ Amjad Hussain, ${ }^{3}$ Abdur Rauf ${ }^{1},{ }^{4}$ Wahid Hussain, ${ }^{5}$ \\ Manzoor Ullah, ${ }^{6}$ Safdar Abbas, ${ }^{7}$ Yahya S. Al-Awthan ${ }^{\mathbb{D},},{ }^{8,9}$ Omar Bahattab ${ }^{(\mathbb{D},}{ }^{8}$ \\ Muhammad Khan, ${ }^{3}$ Ahmed Olatunde, ${ }^{10}$ Zainab M. Almarhoon ${ }^{1 D},{ }^{11}$ Yahia N. Mabkhot, ${ }^{12}$ \\ Mohammed M. Alshehri $\mathbb{D}^{13},{ }^{13}$ Sevgi Durna Daştan, ${ }^{14,15}$ Mohamed Fawzy Ramadan ${ }^{\mathbb{D}},{ }^{16,17}$ \\ and Javad Sharifi-Rad ${ }^{18}$
}

${ }^{1}$ College of Life Science, Anhui Normal University, Wuhu 241000, China

${ }^{2}$ Leibniz Institute of Plant Biochemistry, Department of Bioorganic Chemistry, D-06120 Halle (Saale), Germany

${ }^{3}$ Department of Chemistry, University of Okara, Okara, Pakistan

${ }^{4}$ Department of Chemistry, University of Swabi, Anbar KPK, Pakistan

${ }^{5}$ Department of Botany, Government Post Graduate College Parachinar, Kurram 26000, Pakistan

${ }^{6}$ Department of Botany, University of Science \& Technology Bannu, Pakistan

${ }^{7}$ Department of Biochemistry, Faculty of Biological Sciences, Quaid-i-Azam University, Islamabad, Pakistan

${ }^{8}$ Department of Biology, Faculty of Science, University of Tabuk, Tabuk, Saudi Arabia

${ }^{9}$ Department of Biology, Faculty of Science, Ibb University, Ibb, Yemen

${ }^{10}$ Department of Biochemistry, Abubakar Tafawa Balewa University, Bauchi 740272, Nigeria

${ }^{11}$ Department of Chemistry, College of Science, King Saud University, P.O. Box 2455, Riyadh 11451, Saudi Arabia

${ }^{12}$ Department of Pharmaceutical Chemistry, College of Pharmacy, King Khalid University, Abha, Saudi Arabia

${ }^{13}$ Department of Pharmaceutical Care, Ministry of National Guard-Health Affairs, Riyadh, Saudi Arabia

${ }^{14}$ Department of Biology, Faculty of Science, Sivas Cumhuriyet University, 58140 Sivas, Turkey

${ }^{15}$ Beekeeping Development Application and Research Center, Sivas Cumhuriyet University, 58140 Sivas, Turkey

${ }^{16}$ Deanship of Scientific Research, Umm Al-Qura University, Makkah, Saudi Arabia

${ }^{17}$ Department of Agricultural Biochemistry, Faculty of Agriculture, Zagazig University, Zagazig 44519, Egypt

${ }^{18}$ Facultad de Medicina, Universidad del Azuay, Cuenca, Ecuador

Correspondence should be addressed to Abdur Rauf; abdurrauf@uoswabi.edu.pk,

Mohamed Fawzy Ramadan; hassanienmohamed@yahoo.com, and Javad Sharifi-Rad; javad.sharifirad@gmail.com

Received 14 July 2021; Accepted 9 November 2021; Published 6 December 2021

Academic Editor: Mohammad Nazim

Copyright (c) 2021 Maroof Ali et al. This is an open access article distributed under the Creative Commons Attribution License, which permits unrestricted use, distribution, and reproduction in any medium, provided the original work is properly cited.

Investigation on medicinal plants' therapeutic potential has gained substantial importance in the discovery of novel effective and safe therapeutic agents. The present study is aimed at investigating the hepatoprotective potential of Seriphidium kurramense methanolic extract (SKM) against carbon tetrachloride- $\left(\mathrm{CCl}_{4^{-}}\right)$induced hepatotoxicity in rats. S. kurramense is one of the most imperative plants for its various pharmacological activities. Therefore, this study was aimed at evaluating the hepatoprotective potential against $\mathrm{CCl}_{4}$-induced liver toxicity. The serum samples were analyzed for alanine aminotransferase (ALT) and aspartate aminotransferase (AST) together with the oxidative stress mediator levels as nitric oxide (NO), malondialdehyde (MDA), glutathione (GSH), reduced glutathione $(\mathrm{GSH})$, and superoxide dismutase (SOD) as well as peroxidation and $\mathrm{H}_{2} \mathrm{O}_{2}$ activity. $\mathrm{CCl}_{4}$ administration resulted in an elevated free radical generation, altered liver marker (AST and ALT) enzymes, reduced antioxidant enzyme, and increased DNA damage. Methanolic extract of $S$. kurramense decreased $\mathrm{CCl}_{4}$-induced hepatotoxicity by increasing the antioxidant status and reducing $\mathrm{H}_{2} \mathrm{O}_{2}$ and nitrate content generation as well as reducing DNA damage. Additionally, SKM reversed the morphological alterations induced by $\mathrm{CCl}_{4}$ in the SKM-treated groups. These results demonstrated that SKM displayed hepatoprotective activity against $\mathrm{CCl}_{4}$-induced hepatic damage in experimental rats. 


\section{Introduction}

Seriphidium kurramense (Qazilb) Y.R. Ling is an important medicinal and economic plant of the family Asteraceae and endemic to the tribal district, Upper Kurram, Pakistan, and also transported to different parts of the country for the extraction of new drugs [1]. By surveying the literature, it has been confirmed that several medicinal plants of Pakistan collected from Khyber Pakhtunkhwa, including tribal districts, have been screened out. The earlier studies showed that $S$. kurramense was revealed to have the highest medicinal level and also used for insecticide purposes [1,2]; Kafeel et al., 2018; [2], by clarifying the mechanism underlying the phytochemicals and biological activities of S. kurramense and providing a reference to address protective potential. Carbon tetrachloride $\left(\mathrm{CCl}_{4}\right)$ is a well-renowned industrial solvent known to cause hepatotoxicity. Free radicals derived from $\mathrm{CCl}_{4}$ are involved in covalent binding to the macromolecules, which also cause lipid peroxidation $[3,4]$. It has also been used as a dry-cleaning agent in industries, as a catalyst in polymer reactions, as a solvent in cleaning metals, and as granule fumigant $[5,6]$. Numerous studies have been conducted on $\mathrm{CCl}_{4}$, which showed toxicity in various pathophysiological conditions [7]. Different studies have shown that $\mathrm{CCl}_{4}$ intoxication is constrained to the liver and causes oxidative damage to the tissues of the lung, kidney, heart, brain, testis, and blood $[8,9]$. Due to succeeding $\mathrm{CCl}_{4}$ exposure, lipid peroxide and protein carbonyl levels were identified in tissues isolated from the lung, kidney, and testis of rats [10]. $\mathrm{CCl}_{4}$ requires cytochrome $\mathrm{P} 450$ (phase I system) for the activation of metabolic system in the liver to initiate reactive radical species such as proxy trichloromethyl $\left(\mathrm{OOCCl}_{3}\right)$ and trichloro-4 methyl $\left(\mathrm{CCl}_{3}\right)$, which are involved in increasing lipid peroxidation and protein oxidation causing liver damage [11]. Both radicals are further involved in the initiation of alkoxy (RO) and peroxy (ROO') radicals through their action on the polyunsaturated fatty acids [12]. The silymarin extract obtained from the Silybum marianum is a mixture of polyphenols and flavonoids. Commercially prepared silymarin consists of various flavonoids, such as silidianin and silichristin, isosilibinin (isosilybin A and B), and silibinin (silybin A and B). Silibinin is the key component of this mixture. Silymarin has been found to show antioxidant potential and stabilize the membrane; it also inhibits fibrogenesis, reduces inflammatory reaction, and provokes hepatocyte regeneration. These results were verified through several clinical trials [13-16]. Therefore, the present study was designed with the aim to evaluate their biological activities including hepatoprotective potential of Seriphidium kurramense methanol extract (SKM) against $\mathrm{CCl}_{4}$-induced hepatotoxicity in rats. Our results showed that SKM treatment significantly abolished CCl4-induced hepatotoxicity via attenuating free radical generation, boosting antioxidants, and preventing DNA damage.

\section{Results}

2.1. Effects of SKM on Liver Biomarker Indices. The ALT and AST activities and globulin levels were significantly elevated, while the level of albumin and total protein was decreased in the $\mathrm{CCl}_{4}$-treated rats compared to the control group (Table 1). However, the SKM administration reverses $\mathrm{CCl}_{4}$ effects by reducing ALT and AST activities and the altered level of albumin, globulin, and total protein. Notably, the $\mathrm{SKM}+\mathrm{CCl}_{4}$-treated groups showed results comparable to the group treated with silymarin. Interestingly, SKM effects on the liver biomarkers (ALT, AST, albumin, globulin, and total protein) were recorded to be dose-dependent (Table 1).

2.2. The Effects of SKM on the Activities of CAT, POD, and $S O D$ and the Level of GSH. Table 2 shows the effect of SKM on the activities of antioxidant parameters in experimental animals subjected to $\mathrm{CCl}_{4}$ toxicity. The antioxidant enzyme (CAT, POD, and SOD) activities and the level of GSH were significantly increased in the $\mathrm{CCl}_{4}$-treated rats administered with SKM compared to rats treated with $\mathrm{CCl} 4$ only. The administration of SKM to $\mathrm{CCl}_{4}$-treated rats showed a dose-dependent increase in the activities of CAT, POD, and SOD and the level of GSH. Consistently, the increased antioxidant indices (CAT, POD, SOD, and GSH) were greater in the group treated with SKM only compared to the groups treated with both $\mathrm{SKM}+\mathrm{CCl}_{4}$ as well as the control groups (normal control and silymarin group).

2.3. The Effect of SKM on the Level of TBARS, Nitrite, and $\mathrm{H}_{2} \mathrm{O}_{2}$. The level of TBARs, nitrite, and $\mathrm{H}_{2} \mathrm{O}_{2}$ was recorded to be significantly elevated in the group treated with $\mathrm{CCl}_{4}$ only compared to the groups treated with the SKM and silymarin as well as the control group (Table 3). The elevation recorded of these markers of oxidative stress in the groups treated with $\mathrm{CCl}_{4}$ only was reduced in a dose-dependent manner after SKM administration. The results obtained in the $\mathrm{CCl}_{4}$ groups administered with SKM were comparable to the $\mathrm{CCl}_{4}$ group treated with silymarin.

2.4. SKM Treatment Attenuated $\mathrm{CCl}_{4}$-Induced DNA Injury. The comet and tail length, DNA in the tail, and tail moments were significantly high, while the head length and DNA in the head were significantly low in $\mathrm{CCl}_{4}$-treated rats than in the control group (Figure 1, Table 4). Nevertheless, the administration of SKM to the groups treated with $\mathrm{CCl}_{4}$ ameliorated the DNA damage and was comparable with the group treated with both $\mathrm{CCl}_{4}$ and silymarin. Interestingly, the group treated with solo SKM showed better results compared to the groups treated with both $\mathrm{CC}_{14}$ and SKM (Figure 1, Table 4).

2.5. Defensive Effect of SKM on Histoarchitecture of the Liver. Hematoxylin and eosin are used to stain the thinly sliced sections of liver tissue which were microscopically photographed at $40 \mathrm{x}$ to examine various morphological alterations, as shown in Figure 2. Normal morphology is shown in the control group with the distinctive central vein, Kupffer cells, hepatocytes, and sinusoids (Figure 2). Furthermore, $\mathrm{CCl}_{4}$ treatment caused a noticeable elevation in fatty changes, cellular hypertrophy, inflammatory cell infiltrations, ballooning, and dilation of the central vein in the liver tissues. However, SKM administration $(150 \mathrm{mg} / \mathrm{kg})$ presented the hepatic structure with little fatty changes, dilation 
TABLE 1: Effect of S. kurramense on liver biomarkers.

\begin{tabular}{lccccc}
\hline Treatment & ALT $(\mathrm{mg} / \mathrm{dL})$ & AST $(\mathrm{mg} / \mathrm{dL})$ & Albumin $(\mathrm{mg} / \mathrm{dL})$ & Globulin $(\mathrm{mg} / \mathrm{dL})$ & Tissue protein $(\mu \mathrm{g} / \mathrm{mg}$ tissue $)$ \\
\hline Control (normal) & $38 \pm 2.16^{\mathrm{e}}$ & $42 \pm 2.16^{\mathrm{d}}$ & $4.47 \pm 0.59^{\mathrm{a}}$ & $3.69 \pm 0.38^{\mathrm{b}}$ & $3.26 \pm 0.23^{\mathrm{a}}$ \\
DMSO+olive oil & $37 \pm 2.16^{\mathrm{e}}$ & $43 \pm 2.16^{\mathrm{d}}$ & $4.33 \pm 0.81^{\mathrm{a}}$ & $3.69 \pm 0.42^{\mathrm{b}}$ & $3.25 \pm 0.32^{\mathrm{a}}$ \\
$\mathrm{CCl}_{4}(1 \mathrm{~mL} / \mathrm{kg})$ & $109 \pm 4.19^{\mathrm{a}}$ & $106 \pm 4.11^{\mathrm{a}}$ & $1.95 \pm 0.29^{\mathrm{d}}$ & $4.07 \pm 0.36^{\mathrm{a}}$ & $1.37 \pm 0.16^{\mathrm{c}}$ \\
$\mathrm{CCl}_{4}+$ silymarin & $96 \pm 3.36^{\mathrm{b}}$ & $86 \pm 4.61^{\mathrm{b}}$ & $3.07 \pm 0.37^{\mathrm{b}}$ & $3.94 \pm 0.54^{\mathrm{b}}$ & $2.67 \pm 0.33^{\mathrm{b}}$ \\
$\mathrm{CCl}_{4}+\mathrm{SKM}(150 \mathrm{mg} / \mathrm{mg})$ & $86 \pm 4.42^{\mathrm{c}}$ & $84 \pm 4.42^{\mathrm{b}}$ & $2.46 \pm 0.14^{\mathrm{c}}$ & $3.17 \pm 0.66^{\mathrm{b}}$ & $1.62 \pm 0.42^{\mathrm{c}}$ \\
$\mathrm{CCl}_{4}+\mathrm{SKM}(300 \mathrm{mg} / \mathrm{kg})$ & $72 \pm 3.49^{\mathrm{d}}$ & $58 \pm 3.49^{\mathrm{c}}$ & $3.14 \pm 0.21^{\mathrm{b}}$ & $3.89 \pm 0.19^{\mathrm{b}}$ & $2.75 \pm 0.45^{\mathrm{b}}$ \\
$\mathrm{SKM}(150 \mathrm{mg} / \mathrm{kg})$ & $38 \pm 2.16^{\mathrm{e}}$ & $44 \pm 2.16^{\mathrm{d}}$ & $4.14 \pm 0.44^{\mathrm{a}}$ & $3.59 \pm 0.31^{\mathrm{b}}$ & $3.41 \pm 0.42^{\mathrm{a}}$ \\
SKM $(300 \mathrm{mg} / \mathrm{kg})$ & $39 \pm 2.16^{\mathrm{e}}$ & $42 \pm 2.16^{\mathrm{d}}$ & $4.22 \pm 0.50^{\mathrm{a}}$ & $3.62 \pm 0.46^{\mathrm{b}}$ & $3.31 \pm 0.32^{\mathrm{a}}$ \\
\hline
\end{tabular}

Values are expressed as mean \pm SD (7). Values with different alphabet letters down the column indicate a significant difference $(p<0.05)$. SKM: Seriphidium Kurramense methanol extract.

TABle 2: Effect of S. Kurramense on antioxidant parameters.

\begin{tabular}{|c|c|c|c|c|}
\hline Treatment & CAT (U/min) & $\mathrm{POD}(\mathrm{U} / \mathrm{min})$ & SOD (U/mg protein) & GSH $(\mu \mathrm{M} / \mathrm{g}$ tissue $)$ \\
\hline Control (normal) & $7.3 \pm 0.82^{\mathrm{a}}$ & $9.38 \pm 1.2^{\mathrm{a}}$ & $5.33 \pm 0.75^{\mathrm{a}}$ & $22.46 \pm 1.32^{\mathrm{a}}$ \\
\hline DMSO+olive oil & $7.2 \pm 0.78^{\mathrm{a}}$ & $9.32 \pm 1.17^{\mathrm{a}}$ & $5.23 \pm 0.86^{\mathrm{a}}$ & $22.41 \pm 1.36^{\mathrm{a}}$ \\
\hline $\mathrm{CCl}_{4}(1 \mathrm{~mL} / \mathrm{kg})$ & $2.36 \pm 0.31^{\mathrm{d}}$ & $3.01 \pm 0.33^{\mathrm{d}}$ & $2.03 \pm 0.42^{\mathrm{d}}$ & $6.42 \pm 0.72^{\mathrm{d}}$ \\
\hline $\mathrm{CCl}_{4}+$ silymarin & $5.4 \pm 0.56^{\mathrm{b}}$ & $8.1 \pm 1.12^{\mathrm{b}}$ & $4.12 \pm 0.96^{\mathrm{b}}$ & $18.42 \pm 2.16^{\mathrm{b}}$ \\
\hline $\mathrm{CCl}_{4}+\mathrm{SKM}(150 \mathrm{mg} / \mathrm{mg})$ & $4.6 \pm 0.68^{\mathrm{c}}$ & $6.23 \pm 0.85^{\mathrm{c}}$ & $3.78 \pm 0.42^{c}$ & $14.56 \pm 1.11^{\mathrm{c}}$ \\
\hline $\mathrm{CCl}_{4}+\mathrm{SKM}(300 \mathrm{mg} / \mathrm{kg})$ & $5.9 \pm 0.65^{\mathrm{b}}$ & $8.52 \pm 1.23^{\mathrm{b}}$ & $4.36 \pm 0.76^{\mathrm{b}}$ & $17.23 \pm 1.26^{\mathrm{b}}$ \\
\hline SKM $(150 \mathrm{mg} / \mathrm{kg})$ & $7.3 \pm 0.72^{\mathrm{a}}$ & $9.28 \pm 1.09^{\mathrm{a}}$ & $5.28 \pm 0.62^{\mathrm{a}}$ & $22.32 \pm 1.06^{\mathrm{a}}$ \\
\hline SKM (300 mg/kg) & $7.1 \pm 0.93^{\mathrm{a}}$ & $9.10 \pm 1.11^{\mathrm{a}}$ & $5.24 \pm 0.72^{\mathrm{a}}$ & $22.42 \pm 1.42^{\mathrm{a}}$ \\
\hline
\end{tabular}

SKM: Seriphidium kurramense methanol extract. Values expressed as mean \pm SD (7). Means with different alphabet letters within the column indicate a significant difference $(p<0.05)$.

TABLE 3: Effect of SKM on TBARS, nitrite, and $\mathrm{H}_{2} \mathrm{O}_{2}$ in $\mathrm{CCl}_{4}$-treated rats.

\begin{tabular}{lccc}
\hline Treatment & TBARS $(\mathrm{nM} / \mathrm{min} / \mathrm{mg}$ protein $)$ & Nitrite $(\mu \mathrm{M} / \mathrm{mL})$ & $\mathrm{H}_{2} \mathrm{O}_{2}(\mu \mathrm{M} / \mathrm{mL})$ \\
\hline Control (normal) & $24.56 \pm 2.16^{\mathrm{a}}$ & $49.24 \pm 2.04^{\mathrm{d}}$ & $0.39 \pm 0.09^{\mathrm{e}}$ \\
DMSO+olive oil & $24.47 \pm 2.32^{\mathrm{a}}$ & $49.23 \pm 2.25^{\mathrm{d}}$ & $0.38 \pm 0.08^{\mathrm{e}}$ \\
$\mathrm{CCl}_{4}(1 \mathrm{~mL} / \mathrm{kg})$ & $47.22 \pm 3.17^{\mathrm{b}}$ & $87.68 \pm 4.22^{\mathrm{a}}$ & $1.03 \pm 0.26^{\mathrm{a}}$ \\
$\mathrm{CCl}_{4}+$ silymarin & $28.23 \pm 1.42^{\mathrm{c}}$ & $56.23 \pm 2.17^{\mathrm{c}}$ & $0.52 \pm 0.11^{\mathrm{c}}$ \\
$\mathrm{CCl}_{4}+\mathrm{SKM}(150 \mathrm{mg} / \mathrm{mg})$ & $30.26 \pm 2.42^{\mathrm{c}}$ & $63.01 \pm 2.23^{\mathrm{b}}$ & $0.75 \pm 0.15^{\mathrm{b}}$ \\
$\mathrm{CCl}_{4}+\mathrm{SKM}(300 \mathrm{mg} / \mathrm{kg})$ & $29.43 \pm 2.17^{\mathrm{c}}$ & $58.23 \pm 3.32^{\mathrm{c}}$ & $0.48 \pm 0.08^{\mathrm{c}}$ \\
$\mathrm{SKM}(150 \mathrm{mg} / \mathrm{kg})$ & $24.24 \pm 1.32^{\mathrm{a}}$ & $47.67 \pm 2.31^{\mathrm{d}}$ & $0.38 \pm 0.09^{\mathrm{e}}$ \\
$\mathrm{SKM}(300 \mathrm{mg} / \mathrm{kg})$ & $23.78 \pm 2.36^{\mathrm{a}}$ & $48.03 \pm 2.09^{\mathrm{d}}$ & $0.39 \pm 0.11^{\mathrm{e}}$ \\
\hline
\end{tabular}

SKM: Seriphidium kurramense methanol extract. Values expressed as mean \pm SD (7). Means with different alphabet letters within the column indicate a significant difference $(p<0.05)$.

of the blood vessel, and uniform morphology of hepatocytes similar to the control group. Similarly, silymarin $(50 \mathrm{mg} / \mathrm{kg})$ attenuated the cellular alterations and distractions as expressed. The hepatic histology illustrated that SKM was a higher defensive dose $(300 \mathrm{mg} / \mathrm{kg})$ of SKM.

\section{Discussion}

Carbon tetrachloride $\left(\mathrm{CCl}_{4}\right)$ is a well-known lethal hepatotoxin, and free radical production causes different disorders [17-19]. For centuries, experimental models have been used to investigate mechanisms of oxidant/free radical toxicity in induced chronic disorders [20]. The current study was conceded out to evaluate the ameliorative potential of S. kurra- mense against liver damage in $\mathrm{CCl}_{4}$-treated experimental rats. Our result corroborates with Singh et al. [21], who established the antioxidative properties of Solanum xanthocarpum fruit extract against drug-induced toxicity.

$\mathrm{CCl}_{4}$ induces oxidative stress by free radical generation, causes tissue injury by DNA damage, distressed enzymatic level, and elevated lipid peroxidation. Previously, it has been reported that $\mathrm{CCl}_{4}(1 \mathrm{~mL} / \mathrm{kg})$ administration for 4 weeks at alternating days caused hepatic fibrogenesis, injured the functional reliability of cell membrane and hepatic mitochondrial function, and increased serum enzymes and endogenous antioxidant enzyme pool [22, 23]. Recent studies reveal that CC4-treated rats showed a high intensity of liver markers ALT, AST, and ALP in the serum due to 


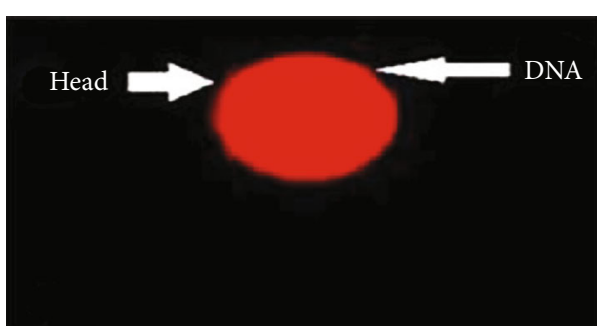

(a)

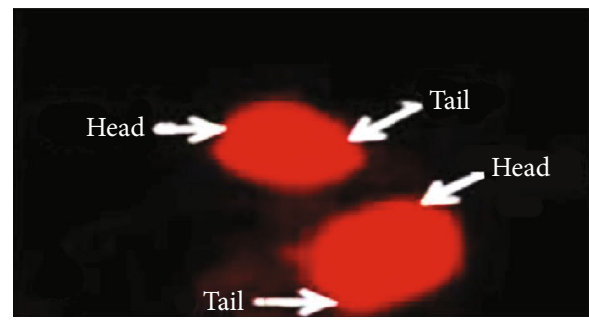

(c)

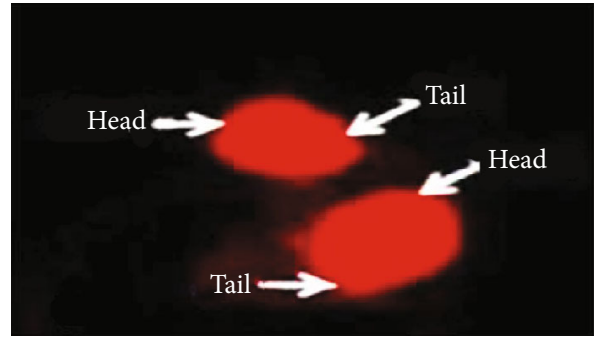

(e)

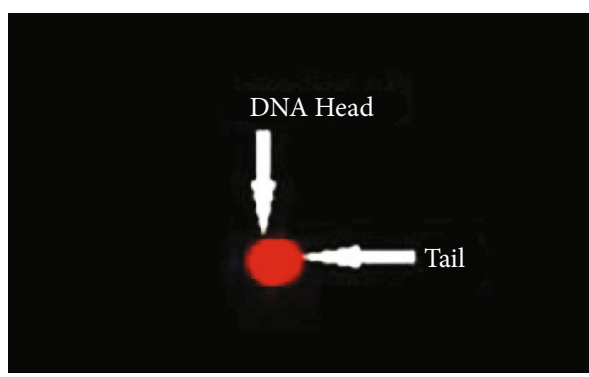

(g)

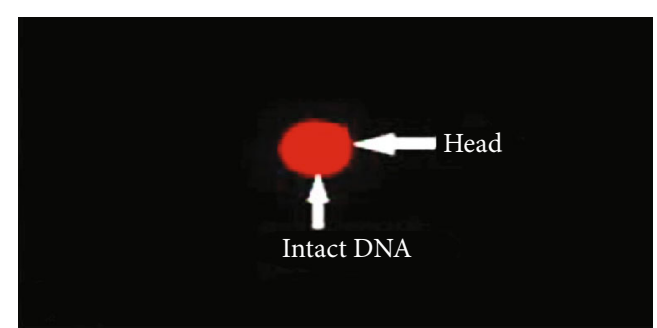

(b)

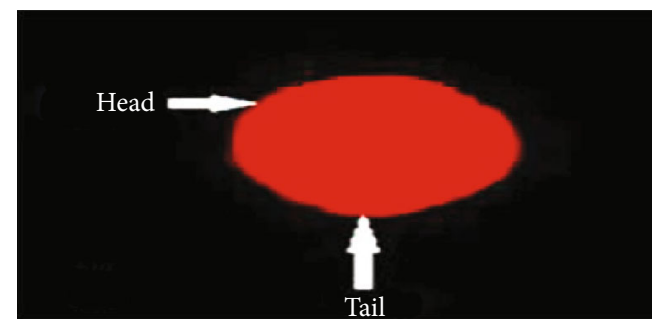

(d)

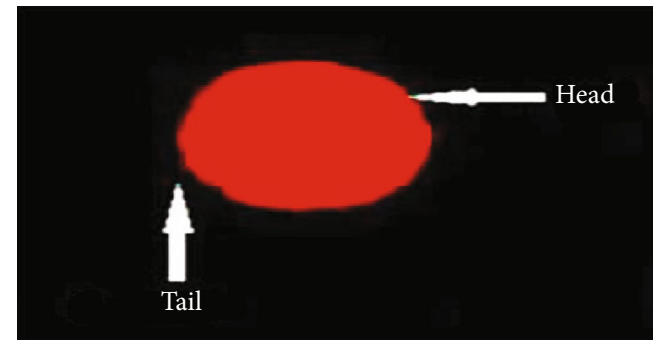

(f)

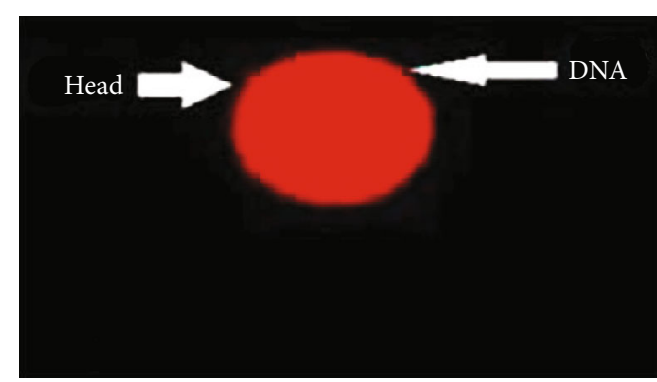

(h)

FIGURE 1: The fluorescence photomicrograph of Seriphidium kurramense methanol extract effect on DNA of hepatic cells: (a) control group, (b) vehicle control, (c) $\mathrm{CCl}_{4}$ only, (d) $\mathrm{CCl}_{4}+$ rutin, (e) $\mathrm{CCl}_{4}+$ low dose $\left(150 \mathrm{mg} / \mathrm{kg}\right.$ ), (f) $\mathrm{CCl}_{4}+$ high dose (300 mg/kg), (g) low dose alone, and (h) high dose alone.

damaged hepatocellular membrane reliability $[12,24]$. In the present study, the plant's methanol extract showed its protective aptitude according to its dose concentration. Moreover, the low dose $(150 \mathrm{mg} / \mathrm{kg})$ was protective, while the protective effect of the high dose $(300 \mathrm{mg} / \mathrm{kg})$ was significantly incoherent with silymarin. Our results are in accordance with the study of Sahreen et al. [12], in which they documented that the antifibrotic effects are caused by the antioxidant activity of Rumex hastatus D. On the other hand, serum activities of AST, ALT, and ALP are related to hepatocyte membrane damage, leaked out into plasma due to the damaged membrane. Singh et al. [25] suggested that the above serum markers' high levels can be the consequence of massive centrilobular necrosis and cellular infiltration in the liver.
Nevin and Vijayammal [8] proposed that compounds and chemicals' toxicological nature can be regularly tested by total protein estimation. Consistent with previous findings herein, $\mathrm{CCl}_{4}$ intoxication reduced protein levels both in the serum and at the tissue level, and SKM treatment reversed these $\mathrm{CCl}_{4}$-induced effects. Furthermore, a high dose of SKM showed more promising and protective effects than a low dose against $\mathrm{CCl}_{4}$-induced protein level dysregulation, suggesting a dose-dependent action of SKM [26]. These results showed that $S$. kurramense is a worthy candidate to inhibit the DNA damage in renal tissues. However, the antioxidant resistance system includes the enzymatic antioxidants (CAT, POD, SOD, GST, and GSH), which contributed a fundamental role in the protective system via scavenging free radicals. It has been reported that $\mathrm{CCl}_{4}$ 
TABLE 4: Effects of SKM on the genotoxic parameters in $\mathrm{CCl}_{4}$-treated rats.

\begin{tabular}{|c|c|c|c|c|c|c|}
\hline Treatment & $\begin{array}{l}\text { Comet length } \\
(\mu \mathrm{m})\end{array}$ & $\begin{array}{l}\text { Head length } \\
(\mu \mathrm{m})\end{array}$ & $\begin{array}{l}\text { Tail length } \\
\qquad(\mu \mathrm{m})\end{array}$ & $\begin{array}{c}\% \text { DNA in the } \\
\text { head }\end{array}$ & $\begin{array}{l}\% \text { DNA in the } \\
\text { tail }\end{array}$ & $\begin{array}{l}\text { Tail moment } \\
(\mu \mathrm{m})\end{array}$ \\
\hline Control (normal) & $62.14 \pm 3.6^{\mathrm{d}}$ & $55 \pm 3.03^{\mathrm{a}}$ & $7.3 \pm 1.11^{\mathrm{d}}$ & $91 \pm 3.03^{\mathrm{a}}$ & $9.01 \pm 1.16^{\mathrm{d}}$ & $31.51 \pm 2.01^{\mathrm{c}}$ \\
\hline DMSO+olive oil & $62.23 \pm 3.4^{\mathrm{d}}$ & $55.5 \pm 3.2^{\mathrm{a}}$ & $7.5 \pm 1.02^{\mathrm{d}}$ & $90 \pm 3.45^{\mathrm{a}}$ & $9.86 \pm 1.37^{\mathrm{d}}$ & $31.42 \pm 2.12^{\mathrm{c}}$ \\
\hline $\mathrm{CCl}_{4}(1 \mathrm{~mL} / \mathrm{kg})$ & $86.21 \pm 4.2^{\mathrm{a}}$ & $44 \pm 3.33^{\mathrm{c}}$ & $42 \pm 2.11^{\mathrm{a}}$ & $65 \pm 2.12^{\mathrm{d}}$ & $35 \pm 2.56^{\mathrm{a}}$ & $41.87 \pm 2.07^{\mathrm{a}}$ \\
\hline $\mathrm{CCl}_{4}+$ silymarin & $65.27 \pm 3.1^{\mathrm{c}}$ & $52.3 \pm 3.1^{\mathrm{b}}$ & $13.9 \pm 1.23^{\mathrm{c}}$ & $86 \pm 3.16^{\mathrm{b}}$ & $14.1 \pm 1.9^{\mathrm{c}}$ & $32.42 \pm 2.01^{\mathrm{c}}$ \\
\hline $\mathrm{CCl}_{4}+\mathrm{SKM}(150 \mathrm{mg} / \mathrm{mg})$ & $73.03 \pm 3.3^{\mathrm{b}}$ & $45 \pm 3.42^{\mathrm{c}}$ & $19 \pm 2.45^{\mathrm{b}}$ & $71.3 \pm 3.1^{\mathrm{c}}$ & $29.5 \pm 2.3^{\mathrm{b}}$ & $36.56 \pm 2.02^{\mathrm{b}}$ \\
\hline $\mathrm{CCl}_{4}+\mathrm{SKM}(300 \mathrm{mg} / \mathrm{kg})$ & $65.78 \pm 3.3^{\mathrm{c}}$ & $45.2 \pm 2.3^{c}$ & $20.58 \pm 1.4^{\mathrm{b}}$ & $87.1 \pm 3.2^{\mathrm{b}}$ & $12.87 \pm 1.1^{\mathrm{c}}$ & $32.54 \pm 2.04^{\mathrm{c}}$ \\
\hline SKM (150 mg/kg) & $61.62 \pm 1.6^{\mathrm{d}}$ & $54.3 \pm 2.4 \mathrm{a}$ & $7.31 \pm 1.9 \mathrm{~d}$ & $91.2 \pm 3.1 \mathrm{a}$ & $9.78 \pm 1.5 \mathrm{~d}$ & $30.50 \pm 2.02 c$ \\
\hline SKM (300 mg/kg) & $62.23 \pm 1.3^{\mathrm{d}}$ & $55.6 \pm 2.2^{\mathrm{a}}$ & $7.63 \pm 1.01^{\mathrm{d}}$ & $90.1 \pm 4.1^{\mathrm{a}}$ & $9.71 \pm 1.13^{\mathrm{d}}$ & $30.47 \pm 2.04^{c}$ \\
\hline
\end{tabular}

SKM: Seriphidium kurramense methanol extract. Values expressed as mean \pm SD (7). Means with different alphabet letters within the column indicate a significant difference $(p<0.05)$.

treatment can cause a significant reduction in the CAT, POD, SOD, GST, and GSH levels [27, 28]. Interestingly, the level of GSH reduced because of its more utilization by the hepatocytes in hunting toxic radicals produced by $\mathrm{CCl}_{4}$. [29] also documented the decline in levels of all enzymes and GSH content in liver tissue by $\mathrm{CCl}_{4}$ supervision. However, SKM treatment enhanced antioxidant enzymes, including CAT, SOD, POD, GST, and GSH level, and decreased under $\mathrm{CCl}_{4}$-induced stress condition [29] using Sonchus asper as a medicinal plant. Furthermore, $\mathrm{CCl}_{4}$ was also showing its toxic belongings by changing the levels of TBARS, $\mathrm{H}_{2} \mathrm{O}_{2}$, tissue protein, and nitrite contents. Peroxidation of lipids provoked overexpression of genetic fibrogenic cytokines by motivating the collagen amalgamation and activating hepatic [30]. Herein, in agreement with previous findings: our results demonstrated reduced protein level and enhanced TBARs, $\mathrm{H}_{2} \mathrm{O}_{2}$, and nitrite content upon $\mathrm{CCl}_{4}$ administration. However, SKM treatment significantly recovered $\mathrm{CCl}_{4}$-induced toxicity by reducing TBARs level, $\mathrm{H}_{2} \mathrm{O}_{2}$ concentration, and nitrite content, likewise the silymarin-treated group. Furthermore, the high-dose treatment of SKM was more effective than the low dose.

Liver regeneration has a significant role in the resistance against chemical-induced damage [31], and its histopathological analysis is the shortest way of evaluating the toxic effect of a drug such as $\mathrm{CCl}_{4}$ and extract of different plants. In our results, liver histological analysis showed a high degree of liver cell damage, fibrosis, necrosis, cellular hypertrophy, and central lobule disruption in the $\mathrm{CCl}_{4}$-treated group compared to the normal subjects; a comparable result has been demonstrated previously by Chen et al. [32]. $\mathrm{CCl}_{4}$ caused oxidative damage to DNA in the mammalian cells has been pragmatic [33]. The single-stranded or doublestranded break in the DNA is because of free radicals, injuring DNA integrity $[34,35]$. Our single-cell gel electrophoresis results showed the extent of DNA damage in the $\mathrm{CCl}_{4}$-treated group compared to the normal subject [36].

Furthermore, an increase in comet tail moment and decline in DNA percentage were observed in $\mathrm{CCl}_{4}$-treated rats compared to the control group. Akram et al. [37] used comet assay to report DNA damage in the rats' ovaries upon sodium arsenate treatment. Sodium arsenate treatment concentration depends on increased oxidative stress in the tis- sues, leading to abnormal oocytes with damaged DNA. And also, it is recommended to study the advanced techniques using SEM analysis for future study [38, 39]. However, in the present investigation, SKM treatment showed an increase in comet head length, DNA percentage, and reduction of comet length, tail length, and moment, as well as DNA percentage in the tail of the comet, suggesting its protecting effects against $\mathrm{CCl} 4$-induced cellular toxicity by preventing DNA damage. Notably, a high dose of SKM was more prominent and significant than a low dose.

\section{Materials and Methods}

4.1. Plant Material and Extraction. Seriphidium kurramense was collected during the spring season in 2018 from Parachinar tribal district, Khyber Pakhtunkhwa (KPK), Pakistan. Dr. Mushtaq Ahmad, Professor at Quaid-i-Azam University Islamabad, identified the plant specimen. Aerial parts of $S$. kurramense were dried under shade and ground to fine powder, and about $2 \mathrm{~kg}$ was pulverized using an electric blender. The finely powdered sample was macerated in $4 \mathrm{~L}$ methanol for two weeks at room temperature. Extract of the plant was completed twice to get their soluble portions using resultant filtrate. Subsequent to obtaining cured methanol extract, particular fraction was ended by the rotary evaporator [40, 41]. Afterward, the plant extract was dried out and kept at $4^{\circ} \mathrm{C}$ for further explorations, while for in vivo analysis, $\mathrm{CCl}_{4}$ was preferred to rouse toxicity in the liver of Sprague Dawley rats as an animal model and to scrutinize them at molecular, biochemical, and tissue level. The mixture was evaporated to dryness; the slurry extract was dried completely at $-70^{\circ} \mathrm{C}$. The mechanism is shown in Figure 3.

4.2. Preparation of $\mathrm{CCl}_{4}$ and $\mathrm{SKM} \mathrm{CCl}_{4}$ was prepared using olive oil as a vehicle. $\mathrm{CCl}_{4}$ was added to the olive oil in the ratio of 30:70 w/w. The intraperitoneal injection of $\mathrm{CCl}_{4}$ mixed with olive oil was carried out for four weeks. Simultaneously, the plant methanol extract was administered at a dose of 150 and $300 \mathrm{mg} / \mathrm{kg}$ body weight. Silymarin was used as the reference drug at a dose of $100 \mathrm{mg} / \mathrm{kg}$ body weight. The various doses of SKM were prepared in DMSO as the vehicle for the plant extract. 


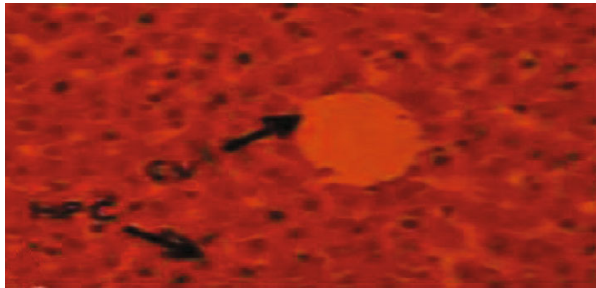

(a)

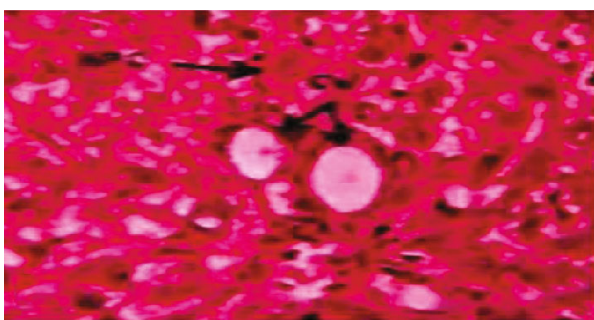

(c)

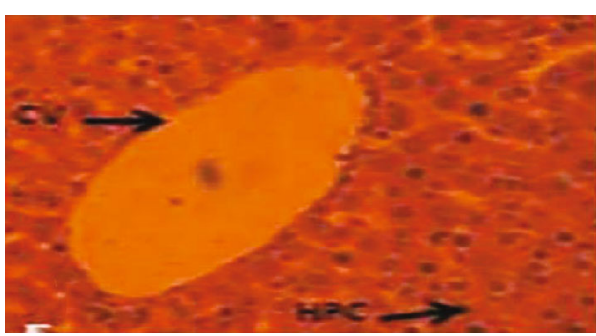

(e)

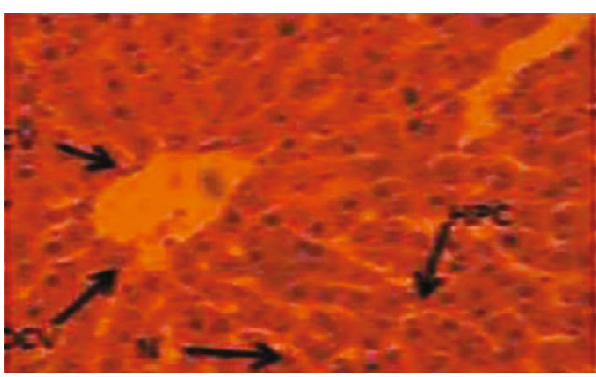

(g)

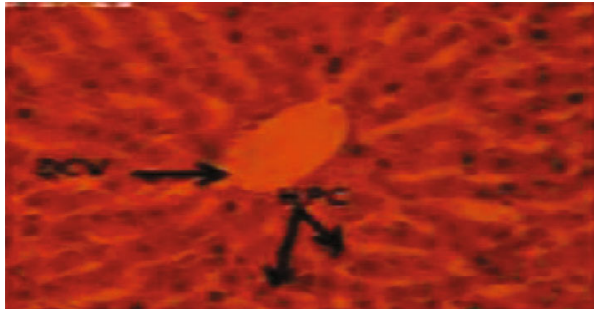

(b)

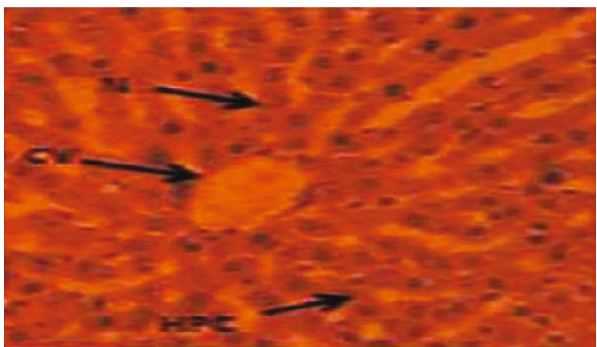

(d)

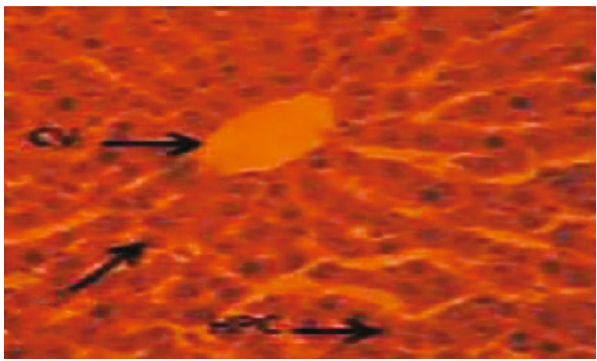

(f)

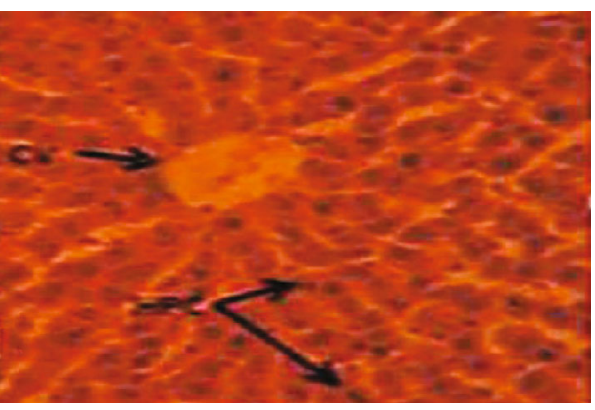

(h)

Figure 2: Liver histopathological observations of control and treated groups at 40x: (a) control, (b) vehicle control, (c) $\mathrm{CCl}_{4}$ only, (d) $\mathrm{CCl}_{4}$ +silymarin $200 \mathrm{mg} / \mathrm{kg}$, (e) $\mathrm{CCl}_{4}+\mathrm{SKM} 150 \mathrm{mg} / \mathrm{kg}$, (f) $\mathrm{CCl}_{4}+\mathrm{SMM} 300 \mathrm{mg} / \mathrm{kg}$, (g) SKM $150 \mathrm{mg} / \mathrm{kg}$, and (h) SKM $300 \mathrm{mg} / \mathrm{kg}$.

4.3. Experiment. Fifty-six rats with $150-200 \mathrm{~g}$ weight were kept at the primate facility in Quaid-i-Azam University, Islamabad, Pakistan. The experimental animals were subjected to $12 \mathrm{~h}$ dark and light cycle, fed on standard rat feeds, and provided with water ad libitum. The methods for animal handling were following the institutional ethical committee's guidelines on scientific research. According to Table 5, the experimental animals were divided into eight groups (each $n=6)$. Group I served as a control, group II contained rats that were treated with DMSO $(10 \%, 1 \mathrm{~mL} / \mathrm{kg})$, group III contained rats treated with $\mathrm{CCl}_{4}$ (i.p) $(1 \mathrm{~mL} / \mathrm{kg})$, group IV received $\mathrm{CCl}_{4}+$ silymarin $(100 \mathrm{mg} / \mathrm{mL} / \mathrm{kg}$ ) (as a reference group), group $\mathrm{V}$ rats received $\mathrm{CCl}_{4}+\mathrm{SKM}(150 \mathrm{mg} / \mathrm{kg}$, orally), group VI received $\mathrm{CCl}_{4}+\mathrm{SKM}(300 \mathrm{mg} / \mathrm{kg}$, orally), group VII received SKM (150 mg/kg orally), and group VIII received SKM (300 $\mathrm{mg} / \mathrm{kg}$ orally).

4.4. Collection of Blood Sample and Isolation of Organs. The experimental rats were subjected to chloroform anesthesia. The jugular vein of the unconscious animal was cut using a sharp disserting blade. The blood samples were collected into clean plain sample bottles. The blood samples were centrifuged for $15 \mathrm{~min}$ at $10,000 \mathrm{rpm}$. After centrifugation, the serum samples were collected and stored in appropriate sample bottles. The animals were dissected, and part of the liver organ was collected, cleaned, and stored in liquid 


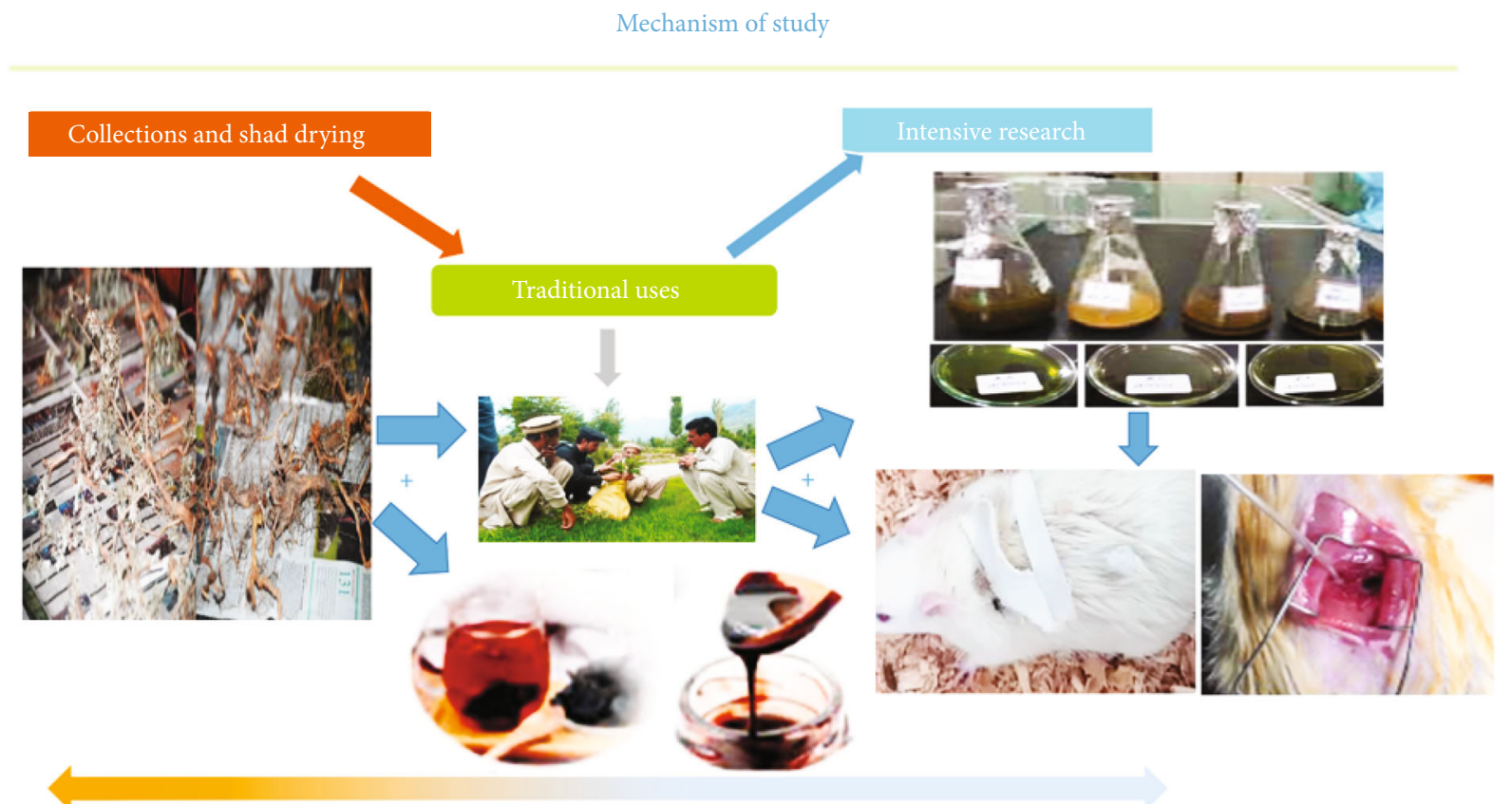

FIGURE 3: Mechanism of Seriphidium kurramense from traditional medicine to in vivo analysis.

TABLE 5: Distribution of animal groups (each containing 6 rats).

\begin{tabular}{|c|c|}
\hline Group (control) & Given no treatment \\
\hline Group 1 (control normal) & Normal healthy feeding \\
\hline Group 2 DMSO+olive oil & Given $10 \%$ DMSO in olive oil orally ( $1 \mathrm{~mL} / \mathrm{kg}$ rat body weight) \\
\hline Group $3\left(\mathrm{CCl}_{4}\right)$ & Given $30 \% \mathrm{CCl}_{4}$ in olive oil i.p ( $1 \mathrm{~mL} / \mathrm{kg}$ rat body weight) \\
\hline Group 4 (silymirin $\left.+\mathrm{CCl}_{4}\right)$ & Given $30 \% \mathrm{CCl}_{4}$ in olive oil i.p ( $1 \mathrm{~mL} / \mathrm{kg}$ rat body weight $)+$ silymarin $(100 \mathrm{mg} / \mathrm{mL}$ in DMSO) orally \\
\hline Group $5\left(\right.$ low dose $\left.+\mathrm{CCl}_{4}\right)$ & $\begin{array}{c}\left.\text { Given } 30 \% \mathrm{CCl}_{4} \text { in olive oil i.p ( } 1 \mathrm{~mL} / \mathrm{kg} \text { rat bodyweight }\right)+S . \text { kurramense methanol (SKM) }(150 \mathrm{mg} / \mathrm{kg} \text { rat body } \\
\text { weight) orally }\end{array}$ \\
\hline Group 6 (high dose $+\mathrm{CCl}_{4}$ ) & $\begin{array}{c}\left.\text { Given } 30 \% \mathrm{CCl}_{4} \text { in olive oil i.p ( } 1 \mathrm{~mL} / \mathrm{kg} \text { rat bodyweight }\right)+S . \text { kurramense methanol (SKM) }(300 \mathrm{mg} / \mathrm{kg} \text { rat body } \\
\text { weight) orally }\end{array}$ \\
\hline Group 7 (SKM) & Given only S. kurramense methanol (SKM) $(150 \mathrm{mg} / \mathrm{kg}$ rat body weight) in DMSO orally \\
\hline Group 8 (SKM) & Given only S. kurramense methanol (SKM) (300 mg/kg rat body weight) in DMSO orally \\
\hline
\end{tabular}

nitrogen at $70^{\circ} \mathrm{C}$ for analysis of tissue homogenates. Following homogenization, the liver homogenate was centrifuged, and the supernatant was collected and was preserved in phosphate buffer formalin $10 \%$, for histopathological observations.

4.5. Biochemical Analysis. ALT (alanine aminotransferase estimation), AST (aspartate aminotransferase estimation), ALP (alkaline phosphatase estimation), and albumin were estimated using diagnostic tools.

4.5.1. Protein Estimation. The full soluble hepatic proteins were anticipated by the technique of Lowry et al. [42]. An amount of $80 \mathrm{mg}$ of tissue was weighed of every organ and homogenized within the phosphate buffer. The organ tissues were centrifuged after homogenization at $10,000 \mathrm{rpm}$ at $4^{\circ} \mathrm{C}$ for $20 \mathrm{~min}$. The $0.1 \mathrm{~mL}$ sample is mixed in $1 \mathrm{~mL}$ basic solution and incubated for $10 \mathrm{~min}$; then, Folin-Ciocalteu reagent was added to each tube with the ratio of $1: 1(\mathrm{v} / \mathrm{v})$ and vortexed. The absorbance was recorded at $595 \mathrm{~nm}$ after
30 min incubation. BSA standard curve was used to determine soluble protein concentration.

4.5.2. Globulin Estimation. Globulin evaluation was carried out using the following formula:total protein - albumin.

\subsubsection{Assessment of Antioxidative Profile}

(1) Catalase Assay (CAT). Catalase action was intended by Chance and Maehly's [42] technique with some changes. For the catalase evaluation, the reaction fusion restricted $2500 \mu \mathrm{L}$ of $50 \mathrm{mM}$ phosphate buffer ( $\mathrm{pH} 7.2$ ), hydrogen peroxide $420 \mu \mathrm{L}(5.9 \mathrm{mM})$, and extract of enzyme $(100 \mu \mathrm{L})$. After $1 \mathrm{~min}$, absorbance alteration of the reaction mixture of the solution was recorded at $240 \mathrm{~nm}$. One entity, catalase activity, was distinct, since at 0.01 units per minute, there is an absorbance change.

(2) Peroxidase Assay (POD). POD assay was resolved by Kakkar et al.'s [4] technique. The reactants of peroxidase 
assay were $1000 \mu \mathrm{L}$ enzyme extract, $100 \mu \mathrm{L}$ guaiacol (20 mM), $300 \mu \mathrm{L} \mathrm{H}_{2} \mathrm{O}_{2}(40 \mathrm{mM})$, and $2500 \mu \mathrm{L} 50 \mathrm{mM}$ phosphate buffer ( $\mathrm{pH}$ 6.8). The absorbance change of the reaction solution was measured after $1 \mathrm{~min}$ at $470 \mathrm{~nm}$. A change of absorbance of 0.01 units per minute's peroxidase activity was observed.

(3) Superoxide Dismutase Assay (SOD). SOD assay was performed using Spitz and Larry's [43] technique. This process was initiated by using $100 \mu \mathrm{L}$ reaction mixture of $186 \mu \mathrm{M}$ PNS (phenazine methosulphate), $1200 \mu \mathrm{L}$ sodium pyrophosphate $(0.052 \mathrm{mM} ; \mathrm{pH}=7.0)$, and supernatant $300 \mu \mathrm{L}$ derived from the homogenate of the liver, which was integrated into the reaction mixture. The entire mixture was subjected to centrifugation for $10 \mathrm{~min}$ at $1500 \mathrm{rpm}$ and after that at $10000 \mathrm{rpm}$ for $15 \mathrm{~min}$. The enzyme's reaction started with the addition of $0.2 \mathrm{~mL}$ of $780 \mu \mathrm{M}$ NADH and followed by the addition of $1000 \mu \mathrm{L}$ glacial acetic acid. The intensity of color estimated the amount of chromogen produced at an absorbance of $560 \mathrm{~nm}$, and the results were recorded in units per milligram.

(4) Glutathione S-Transferase Assay (GST). To evaluate GST, Habig et al.'s [44] method was used. The summary of all the reactants for this test includes $200 \mu \mathrm{L}$ of reduced glutathione of $1 \mathrm{mM}, 1475 \mu \mathrm{L}$ phosphate buffer of $0.1 \mathrm{M}(\mathrm{pH}=6.5)$, and enzyme extract of $300 \mu \mathrm{L}$, in a total volume of $2000 \mu \mathrm{L}$. At the absorbance of $340 \mathrm{~nm}$, a change was observed. The activity of enzymes was assessed throughout with the formation of $M$ conjugate per minute. The extermination molarity, $9.6 \times 103 \mathrm{M}^{-1} \mathrm{~cm}^{-1}$, was used as a coefficient here.

(5) Reduced Glutathione Assay (GSH). The assay was performed using Jollow et al.'s [45] protocol. The homogeneous mixture of the sample contained $1000 \mu \mathrm{L}$ of $4 \%$ sulfosalicylic acid. The appetizer was kept at $4^{\circ} \mathrm{C}$ for $1 \mathrm{~h}$ and centrifuged for the next $20 \mathrm{~min}$ at $4^{\circ} \mathrm{C}(1200 \mathrm{~g})$. The entire $3000 \mu \mathrm{L}$ volume of the reactant mixture included $100 \mu \mathrm{L}$ clean aliquot, $200 \mu \mathrm{L}$ DTNB $(100 \mathrm{mM})$, and $2700 \mu \mathrm{L}$ phosphate buffer $(0.1 \mathrm{M} ; \mathrm{pH}=7.4)$. The color (yellow) variation at various combinations of the reactants was calculated instantly by maintaining $412 \mathrm{~nm}$ of the absorbance. Reduced glutathione action was articulated as micromolar GSH per gram tissue piece.

(6) Lipid Peroxidation (TBARS). This original assay was conducted using Iqbal and Wright's [46] method. The whole $1000 \mu \mathrm{L}$ of the main reacting sample included $0.1 \mathrm{M}$ phosphate buffer $\left(\begin{array}{ll}580 & \mu \mathrm{L}\end{array}\right)$ maintained at $\mathrm{pH} 7.4$, homogenate sample $(200 \mu \mathrm{L})$, the $100 \mathrm{mM}$ of ascorbic acid $(200 \mu \mathrm{L})$, and $100 \mathrm{mM}$ ferric chloride $(20 \mu \mathrm{L})$. The whole reacting sample was kept at $37^{\circ} \mathrm{C}$ for $1 \mathrm{~h}$ in the incubator. The $1000 \mu \mathrm{L}$ of $10 \%$ trichloroacetic acid was added to block the reaction. The sample tubes were inserted in hot water maintained at $100^{\circ} \mathrm{C}$, followed by adding $0.67 \%$ thiobarbituric $(1000 \mu \mathrm{L})$ for $20 \mathrm{~min}$, and next positioned on the compressed ice-bath, and then, centrifugation for $10 \min (2500 \times \mathrm{g})$ was started. The amount of TBARS (lipid peroxidation) in every sample was premeditated by captivating the absorbance of supernatant against a blank reagent on a spectrophotometer at $535 \mathrm{~nm}$. The outcomes were uttered using $1.56 \times 105 \mathrm{M}^{-1} \mathrm{~cm}^{-1}$ molar destruction coefficient for TBARS per minute per milligram tissues at $37^{\circ} \mathrm{C}$.

(7) Hydrogen Peroxide Assay $\left(\mathrm{H}_{2} \mathrm{O}_{2}\right) \cdot \mathrm{H}_{2} \mathrm{O}_{2}$ activity was executed following the Pick and Keisari's [47] protocol through umpired horseradish peroxidase-reliant oxidation of phenol red. The main constituents included $0.5 \mathrm{M}$ phosphate buffer $(\mathrm{pH}=7.0), 8.5$ units of horseradish peroxidase, $5.5 \mathrm{nM}$ dextrose, and $2 \mathrm{~mL}$ of a homogenate of tissue (hanging in $1000 \mu \mathrm{L}$ of a solution of $0.28 \mathrm{nM}$ phenol red), and the whole mixture of the sample was incubated for $60 \mathrm{~min}$ at $37^{\circ} \mathrm{C}$ followed by addition of $10 \mu \mathrm{L}$ of $1 \mathrm{~N}$ sodium hydroxide to cease further reaction. The centrifugation was performed at $800 \times \mathrm{g}$ for $5 \mathrm{~min}$. At the wavelength of $610 \mathrm{~nm}$, the supernatant's absorbance against the blank reagent was calculated. The $n M H_{2} \mathrm{O}_{2}$ was fed in milligram per minute per tissue using standard curve $\mathrm{H}_{2} \mathrm{O}_{2}$ oxidized phenol red.

(8) Nitrite Assay. Grisham et al. [48] experimented to authenticate the nitrite assess. The Griess reagent was used in this experiment. The sample ( $100 \mathrm{mg}$ tissue homogenate) was deproteinized with $5 \% \quad \mathrm{ZnSO}_{4}$ and $0.3 \mathrm{M} \mathrm{NaOH}$ $(100 \mu \mathrm{L})$. The entire mixture was subjected to $15-20 \mathrm{~min}$ of centrifugation at $6400 \times \mathrm{g}$. A volume of $1 \mathrm{~mL}$ Griess reagent along with $20 \mu \mathrm{L}$ supernatant was added in the cuvette. The absorbance of the reaction mixture was recorded at $540 \mathrm{~nm}$. The curve of $\mathrm{NaNO}_{2}$ was used for evaluating the quantity of nitrite in samples.

(9) Histopathological Study of Tissues. The paraffin-rooted bruising route finished histopathology of tissue appraisal. The different steps demand obsession with a biological taster in sticky stuff, safeguarding their morphology, and avert the tissue decomposes. Consequently, the new hepatic tissues were segmented into tiny sections and set in $10 \%$ formalin. The preset tissues were more soaked, and progression in the way of a mounting succession of $50 \%, 70 \%, 90 \%$, and $100 \%$ alcohol, heading for the tissues, maintains on a rigid solid medium and, consequently, assists slight segments to be incised. The tissues were safe on tough solid wedges, using paraffin-implanting. Slides were fixed by slicing skinny strata of the fixed-tissue tasters 3-4 $\mu \mathrm{m}$ through staining with eosin and hematoxylin. Finally, the examination of slides was carried out in the light microscope (DIALUX $20 \mathrm{~EB}$ ) at $10 \mathrm{x}$ and $40 \mathrm{x}$ and pictures using an HDCE-50B camera were taken.

(10) Comet Assay. To determine the DNA damage, the protocol of Dhawan et al. [29] with some modifications was used.

(11) Lysing Solution. The fusion of solution was made by adding $1.46 \mathrm{~g}$ of $2.5 \mathrm{M} \mathrm{NaOH}, 1.2 \mathrm{~g}$ of $100 \mathrm{mM}$ Trizma base, and $37.2 \mathrm{~g}$ of $100 \mathrm{mM}$ EDTA into $700 \mathrm{~mL}$ distilled water. By the addition of $\mathrm{HCl}$ or $\mathrm{NaOH}, \mathrm{pH}$ was adjusted to 10 . 
Adjustment of entire volume was made equal to $890 \mathrm{~mL}$ through distilled $\mathrm{H}_{2} \mathrm{O}$. DMSO and Triton $\mathrm{X}$ increase the volume up to the required level, and then, a solution was placed on standby at room temperature. Later on, 10\% DMSO and $1 \%$ Triton $\mathrm{X}$ were added to result in the lysing solution's final state. The whole solution was kept in the refrigerator for $30 \mathrm{~min}$.

(12) PBS Buffer $\left(\mathrm{Mg}^{2+}, \mathrm{Ca}^{2+}\right)$. It was diluted by $990 \mathrm{~mL}$ distilled water, and the final volume reached up to $1000 \mathrm{~mL}$ at room temperature and regulated at $\mathrm{pH}$ 7.4.

(13) Electrophoresis Buffer. Intended for $1 \mathrm{X}$ buffer groundwork in distilled $\mathrm{H}_{2} \mathrm{O}, 30 \mathrm{~mL} \mathrm{NaOH}$ was added to $0.5 \mathrm{~mL}$ of $200 \mathrm{mM}$ EDTA, and the whole volume was taken up to $1000 \mathrm{~mL}$. At room temperature, $\mathrm{pH}$ was fixed at less than 1 .

Neutralization buffer: $48.5 \mathrm{~g}$ of $0.4 \mathrm{M}$ Tris was mixed with $1 \mathrm{~L}$ of distilled water, and conc. $\mathrm{HCl}$ was added at room temperature to fixed $\mathrm{pH}$ of 7.5 .

Staining solution: $30 \mu \mathrm{g} / \mathrm{mL}$ stock solution of $10 \mathrm{X}$ ethidium bromide. Ten milligrams of ethidium bromide was added to $50 \mathrm{~mL}$ dist. $\mathrm{H}_{2} \mathrm{O}$ to obtain ethidium bromide solution. This solution was used as a staining agent. A.0.5\% of low melting point agarose (LMPA) was all set through the amalgamation of $250 \mathrm{mg}$ of low melting point agarose in $1 \%$ PBS solution $(50 \mathrm{~mL})$. Refrigeration was stopped, and temperature was stabilized at $37^{\circ} \mathrm{C}$ by putting in water bath earlier to use a $1 \%$ normal melting agarose (NMA). This solution resulted by adding $500 \mathrm{mg}$ of NMA in $50 \mathrm{~mL} \mathrm{H} \mathrm{H}_{2} \mathrm{O}$. Suspension of the gel is formed by heating $\mathrm{MA}$ in $50 \mathrm{~mL}$ water.

4.6. Preparation of Slides. The NMA and LMPA solutions were all set for the slide preparation, as illustrated earlier. Slides were set via sinking in methanol and burn up over a fire to get rid of dirt. The small portion of the slide was sunk in warm NMA agarose and subsequently took away gradually. Dirt-free inferior surface was kept in a dish designed for solidification. The slides were dried in the air, tagged, and placed at ordinary temperature. For the extraction purpose, a minute portion of tissue was placed in a cold solution of HBSS $(1 \mathrm{~mL})$ containing DMSO and EDTA in a ratio of $10: 20$. Small pieces of tissues were crushed, followed by the addition of $75 \mu \mathrm{L} \mathrm{LMPA}$ in it. On stored slides, this blend was coated and enclosed by a coverslip. Slides were placed in ice packs for the solidification of gel. After 5$10 \mathrm{~min}$, gradually remove the coverslips and third coat by addition of $80 \mu \mathrm{L}$ of LMPA on the same slide; using the ice packs, they were made dried. This was further followed by removing the coverslips and putting slides in lysing solution. Sides were protected from the light and chilled for $2 \mathrm{~h}$.

4.7. Electrophoresis. After staying for $2 \mathrm{~h}$ in lysing solution, the slides were removed adjusted with a flat gel kit. The newly equipped buffer was dispensed in a gel container, and every slide was placed in the buffer for 20 mins to unzip DNA. At 24 volts, the electric supply was switched on for $30 \mathrm{~min}$. Slides were gradually taken away, and next is the addition of neutralizing buffer. A similar practice was repeated again and again. A $80 \mu \mathrm{L}$ of $1 \mathrm{X}$ ethidium bromide staining was done, and slides were covered with coverslips.

4.8. Slide Visualization. DNA damage was recognized through a fluorescent microscope at 40x. The degree of DNA injury was determined through the software of image investigation CASP 1.2.3. At the same time, approximating the proportion of transferred DNA and also emigrational span was done. Usually, in all tasters, 50 to100 cells were studied. To analyze the relationship between the quantities of per cell migration, numbers of cells with improved migration, feasibility, and emigrational aptitude among injured cells were counted.

\section{Conclusion for Future Biology}

Seriphidium kurramense possessed potent potential against $\mathrm{CCl}_{4}$-induced hepatotoxicity by reducing oxidative and nitrosative stress, boosting antioxidant capacities, and reducing cellular toxicity attenuating DNA damage. Moreover, the inspected plant might be measured as an impressive natural cause to widen novel drugs and present a feasible significance of treating various diseases in the mounting world.

$\begin{array}{ll}\text { Abbreviations } \\ \mathrm{CCl}_{4}: & \text { Carbon tetrachloride } \\ \mathrm{H}_{2} \mathrm{O}_{2}: & \text { Hydrogen peroxide } \\ \mathrm{OOCC}_{3}: & \text { Proxy trichloromethyl } \\ \mathrm{CCl}_{3}: & \text { Trichloro-4 methyl } \\ \mathrm{RO}: & \text { Alkoxy radical } \\ \text { ROO: } & \text { Peroxy radical } \\ \mathrm{CAT}: & \text { Catalase assay } \\ \text { POD: } & \text { Peroxidase assay } \\ \text { SOD: } & \text { Superoxide dismutase assay } \\ \text { GST: } & \text { Glutathione S-transferase assay } \\ \text { GSH: } & \text { Reduced glutathione assay } \\ \text { TBARS: } & \text { Estimation of lipid peroxidation } \\ \text { PBS: } & \text { Phosphate-buffered saline } \\ \text { LMPA: } & \text { Low melting point agarose } \\ \text { NMA: } & \text { Normal melting agarose } \\ \text { DMSO: } & \text { Dimethyl sulfoxide } \\ \text { EDTA: } & \text { Ethylenediaminetetraacetic acid } \\ \text { DNA: } & \text { Deoxyribonucleic acid } \\ \text { CASP: } & \text { Critical Appraisal Skills Programme } \\ \text { SKM: } & \text { Seriphidium kurramense methanol extract } \\ \text { ALT: } & \text { Alanine aminotransferase estimation } \\ \text { AST: } & \text { Aspartate aminotransferase estimation } \\ \text { ALP: } & \text { Alkaline phosphatase estimation. } \\ & \end{array}$

\section{Data Availability}

The data used to support the findings of this study are available from the corresponding author upon request.

\section{Conflicts of Interest}

The authors claim no conflict of interest for the work conducted in this manuscript. 


\section{Authors' Contributions}

M.A. and H.H. collected plants, performed experiments, collected and analyzed data, and drafted the manuscript. $\mathrm{AH}$ supervised the whole experimental work and helped mainly in the write-up. A.R., W.H., and MU have put a lot of their input in the designing and critical writing of the bioactivity part of this work. S.A., Y.S.A., O.B., M.K., A.O., Z.M.A, J.S.-R., and Y.N.M.B. Involved in analysis and editing of paper. M.M.A., S.D.D., M.F.R., and J.S.-R. revised the manuscript and help in arranging data in tables. All authors read the paper and approve it for submission.

\section{Acknowledgments}

The authors extend their appreciation to the Deanship of Scientific Research at King Khalid University for funding this work through Research group Project under grant number R.G.P. 1/39/42.

\section{References}

[1] S. A. Gilani, M. Sugano, Y. Fujii, and K. N. Watanabe, "Chemotypic variations and phytotoxic studies of essential oils of endemic medicinal plant, Seriphidium kurramense, from Pakistan," Journal of Medicinal Plant Research: Planta Medica, vol. 4, no. 4, pp. 309-315, 2010.

[2] M. Ali, A. Aldosari, D. Y. Tng et al., "Traditional uses of plants by indigenous communities for veterinary practices at Kurram district, Pakistan," Ethnobotany Research and Applications, vol. 18, pp. 1-19, 2019.

[3] S. S. Azab, M. Abdel-Daim, and O. A. Eldahshan, "Phytochemical, cytotoxic, hepatoprotective and antioxidant properties of Delonix regia leaves extract," Medicinal Chemistry Research, vol. 22, no. 9, pp. 4269-4277, 2013.

[4] P. Kakkar, P. Das, and P. N. Viswanathan, "A modified spectrophotometric assay of superoxide dismutase," Indian Journal of Biochemistry \& Biophysics, vol. 21, no. 2, pp. 130-132, 1984.

[5] M. Jain, R. Kapadia, R. N. Jadeja, M. C. Thounaojam, and R. V. Devkar, "Cytotoxicity evaluation and hepatoprotective potential of bioassay guided fractions from Feronia limmonia Linn leaf," Asian Pacific Journal of Tropical Biomedicine, vol. 1, no. 6, pp. 443-447, 2011.

[6] W. Hussain, L. Badshah, M. Ullah, M. Ali, A. Ali, and F. Hussain, "Quantitative study of medicinal plants used by the communities residing in Koh-e-Safaid Range, northern Pakistani-Afghan borders," Journal of Ethnobiology and Ethnomedicine, vol. 14, no. 1, p. 30, 2018.

[7] R. A. Jacob and G. Sotoudeh, "Vitamin C function and status in chronic disease," Nutrition in Clinical Practice, vol. 2, pp. 66-74, 2002.

[8] K. Nevin and P. Vijayammal, "Effect of Aerva lanata on solid tumor induced by DLA cells in mice," Fitoterapia, vol. 74, no. 6, pp. 578-582, 2003.

[9] W. Hussain, J. Hussain, R. Ali et al., "Phytomedicinal studies of Kurram Agency in the federally administered tribal areas (FATA) of Pakistan," Journal of Applied Pharmaceutical Science, vol. 2, no. 10, pp. 81-85, 2012.

[10] A. P. Manjrekar, V. Jisha, P. P. Bag, B. Adhikary, and M. M. Pai, "Effect of Phyllanthus niruri Linn. treatment on liver, kid- ney and testes in $\mathrm{CCl}_{4}$ induced hepatotoxic rats," Indian Journal of Experimental Biology, vol. 46, no. 1, pp. 514-520, 2008.

[11] S. N. Desai, D. K. Patel, R. V. Devkar, P. V. Patel, and A. V. Ramachandran, "Hepatoprotective potential of polyphenol rich extract of Murraya koenigii L.: An in vivo study," Food and Chemical Toxicology, vol. 50, no. 2, pp. 310-314, 2012.

[12] S. Sahreen, M. R. Khan, and R. A. Khan, "Phenolic compounds and antioxidant activities of Rumex hastatus D Don. Leaves," Journal Med Plant Res, vol. 5, no. 3, pp. 2755-2765, 2011.

[13] P. Ferenci, B. Dragosics, H. Dittrich, H. Frank, and L. Benda, "Randomized controlled trial of silymarin treatment in patients with cirrhosis of the liver," Journal of Hepatology, vol. 9, no. 1, pp. 105-113, 1989.

[14] B. M. Kus, C. E. Caldon, R. Andorn-Broza, and A. M. Edwards, "Functional interaction of 13 yeast SCF complexes with a set of yeast E2 enzymes in vitro," Proteins, vol. 54, no. 3, pp. 455467, 2004.

[15] R. Saller, R. Brignoli, J. Melzer, and R. Meier, “An updated systematic review with meta-analysis for the clinical evidence of silymarin," Forschende Komplementärmedizin / Research in Complementary Medicine, vol. 15, no. 1, pp. 9-20, 2008.

[16] R. Saller, J. Melzer, J. Reichling, R. Brignoli, and R. Meier, "An updated systematic review of the pharmacology of silymarin," Complementary Medicine Research, vol. 14, no. 2, pp. 70-80, 2007.

[17] L. P. Xiao, Z. J. Shi, F. Xu, and R. C. Sun, "Hydrothermal carbonization of lignocellulosic biomass," Bioresource Technology, vol. 118, no. 1, pp. 619-623, 2012.

[18] R. Jayakumar, D. Menon, K. Manzoor, S. V. Nair, and H. Tamura, "Biomedical applications of chitin and chitosan based nanomaterials-A short review," Carb Polym82, vol. 82, no. 2, pp. 227-232, 2010.

[19] I. Ozturk, M. Altinbas, I. Koyuncu, O. Arikan, and C. GomecYangin, "Advanced physico-chemical treatment experiences on young municipal landfill leachates," Waste Management, vol. 23, no. 5, pp. 441-446, 2003.

[20] S. Basu, "Carbon tetrachloride-induced lipid peroxidation: eicosanoid formation and their regulation by antioxidant nutrients," Toxicology, vol. 189, no. 1-2, pp. 113-127, 2003.

[21] H. Singh, A. Prakash, A. N. Kalia, and A. B. A. Majeed, "Synergistic hepatoprotective potential of ethanolic extract of Solanum xanthocarpum and Juniperus communis against paracetamol and azithromycin induced liver injury in rats," Journal of Traditional and Complementary Medicine, vol. 6, no. 4, pp. 370-376, 2016.

[22] M. Ibrahim, E. Farghaly, W. Gomaa, M. Kelleni, and A. M. Abdelrahman, "Nitro-aspirin is a potential therapy for nonalcoholic fatty liver disease," European Journal of Pharmacology, vol. 659, no. 2-3, pp. 289-295, 2011.

[23] P. Abraham and G. Wilfred, "Oxidative damage to the lipids and proteins of the lungs, testis, and kidney of rats during carbon tetrachloride intoxication," Clinica Chimica Acta, vol. 289, no. 1, pp. 177-179, 1999.

[24] S. Sahreen, M. R. Khan, and R. A. Khan, "Phenolic compounds and antioxidant activities of Rumex hastatus D Don Leaves," $J$. Med. Plants Res, vol. 5, no. 13, pp. 2755-2765, 2011.

[25] R. Singh, S. Kaushik, Y. Wang, Y. Xiang, and I. Novak, "Autophagy regulates lipid metabolism," Nature, vol. 458, no. 7242, pp. 1131-1135, 2009.

[26] A. Brazma, P. Hingamp, J. Quackenbush, G. Sherlock, and P. Spellman, "Minimum information about a microarray 
experiment (MIAME)-toward standards for microarray data," Nature Genetics, vol. 29, no. 4, pp. 365-371, 2001.

[27] G. Weber, "Vitamin D induces the antimicrobial protein hCAP18 in human skin," Journal of Investigative Dermatology, vol. 124, no. 5, pp. 1080-1082, 2005.

[28] X. Zhang, X. Xie, H. Wang, J. Zhang, and B. Pan, "Enhanced photoresponsive ultrathin graphitic-phase C3N4 nanosheets for bioimaging," Journal of the American Chemical Society, vol. 135, no. 1, pp. 18-21, 2013.

[29] A. Dhawan and D. Anderson, Eds., The Comet Assay in Toxicology. RSC, vol. 30, United Kingdom, Cambridge, 2016.

[30] K. H. Janbaz and A. H. Gilani, "Evaluation of the protective potential of Artemisia maritima extract on acetaminophenand $\mathrm{CCl}_{4}$-induced liver damage," Journal of Ethnopharmacology, vol. 47, no. 1, pp. 43-47, 1995.

[31] S. Sadasivan, P. G. Latha, J. M. Sasikumar, S. Rajashekaran, and S. Shyamal, "Hepatoprotective studies on Hedyotis corymbosa (L.) Lam.," Journal of Ethnopharmacology, vol. 106, no. 2, pp. 245-249, 2006.

[32] I. N. Chen, C. C. Chang, C. Y. Wang, Y. T. Shyu, and T. L. Chang, "Antioxidant and antimicrobial activity of Zingiberaceae plants in Taiwan," Plant Foods for Human Nutrition, vol. 63, no. 1, pp. 15-20, 2008.

[33] S. K. Das and D. Vasudevan, "Alcohol-induced oxidative stress," Life Sciences, vol. 81, no. 3, pp. 177-187, 2007.

[34] N. K. A. Tukappa, R. L. Londonkar, H. B. Nayaka, and C. B. S. Kumar, "Cytotoxicity and hepatoprotective attributes of methanolic extract of Rumex vesicarius L," Biological Research, vol. 48 , no. 1, 2015.

[35] M. Ogeturk, I. Kus, N. Colakoglu, I. Zararsiz, and N. Ilhan, "Caffeic acid phenethyl ester protects kidneys against carbon tetrachloride toxicity in rats," Journal of Ethnopharmacology, vol. 97, no. 2, pp. 273-280, 2005.

[36] H. Heilborn and D. Johan, "Antimicrobial protein hCAP18/ LL-37 is highly expressed in breast cancer and is a putative growth factor for epithelial cells," International Journal of Cancer, vol. 114, no. 5, pp. 713-719, 2005.

[37] Z. Akram, S. Jalali, S. A. Shami, L. Ahmad, S. Batool, and O. Kalsoom, "Genotoxicity of sodium arsenite and DNA fragmentation in ovarian cells of rat," Toxicology, vol. 190, no. 1, pp. 81-85, 2009.

[38] M. Ali, S. Bahadur, A. Hussain et al., "Foliar epidermal micromorphology and its taxonomic significance in Polygonatum (Asparagaceae) using scanning electron microscopy," Microscopy Research and Technique, vol. 83, no. 11, pp. 1381-1390, 2020.

[39] M. Ali, Y.-J. Liu, Q.-P. Xia et al., "Pollen micromorphology of eastern ChinesePolygonatumand its role in taxonomy by using scanning electron microscopy," Microscopy Research and Technique, vol. 84, no. 7, pp. 1451-1461, 2021.

[40] H. Y. Kil, E. S. Seong, B. K. Ghimire et al., "Antioxidant and antimicrobial activities of crude sorghum extract," Food Chemistry, vol. 115, no. 4, pp. 1234-1239, 2009.

[41] M. H. Shyu, T. C. Kao, and G. C. Yen, "Hsian-tsao (Mesona procumbens $\mathrm{Heml}$ ) prevents against rat liver fibrosis induced by $\mathrm{CCl}_{4}$ via inhibition of hepatic stellate cells activation," Food and Chemical Toxicology, vol. 46, no. 12, pp. 3707-3713, 2008.

[42] B. Chance and A. C. Maehly, "Assay of catalases and peroxidases:," Methods Enzymol2, pp. 764-775, 1955.
[43] D. R. Spitz and W. O. Larry, "An assay for superoxide dismutase activity in mammalian tissue homogenates," Analytical Biochemistry, vol. 179, no. 1, pp. 8-18, 1989.

[44] W. H. Habig, M. J. Pabst, and W. B. Jakoby, "Glutathione STransferases: the first enzymatic step in mercapturic acid formation," The Journal of Biological Chemistry, vol. 249, no. 22, pp. 7130-7139, 1974.

[45] D. J. Jollow, J. R. Mitchell, N. A. Zampaglione, and J. R. Gillette, "Bromobenzene-induced liver necrosis. Protective role of glutathione and evidence for 3, 4-bromobenzene oxide as the hepatotoxic metabolite," Pharmacology, vol. 11, no. 3, pp. 151-169, 1974.

[46] M. Iqbal and D. J. Wright, "Host resistance to insecticides can confer protection to endo-larval parasitoids," Bulletin of Entomological Research, vol. 86, no. 6, pp. 721-723, 1996.

[47] E. Pick and Y. Keisari, "Superoxide anion and hydrogen peroxide production by chemically elicited peritoneal macrophages-Induction by multiple nonphagocytic stimuli," Cellular Immunology, vol. 59, no. 2, pp. 301-318, 1981.

[48] B. Grisham Matthew, G. Glenda, J. R. Johnson, and L. Jr, "Quantitation of nitrate and nitrite in extracellular fluids," Methods in Enzymology, vol. 268, pp. 237-246, 1996. 